\title{
Oxidative stress-induced aberrant G9a activation disturbs RE-1-containing neuron-specific genes expression, leading to degeneration in human SH-SY5Y neuroblastoma cells
}

\author{
Ho-Tae Kim ${ }^{1,2, \#}$, Takbum Ohn ${ }^{3, \#}$, Sin-Gu Jeong ${ }^{1,2,4}$, Anji Song ${ }^{1,2}$, Chul Ho Jang ${ }^{5}$, and Gwang-Won Cho ${ }^{1,2, *}$ \\ ${ }^{1}$ Department of Biology, College of Natural Science, Chosun University, ${ }^{2}$ Department of Integrative Biological Science, BK21 FOUR Education Research Group \\ for Age-Associated Disorder Control Technology, Chosun University, ${ }^{3}$ Department of Cellular and Molecular Medicine, College of Medicine, Chosun University, \\ Gwangju 61452, ${ }^{4}$ Department of Bio Research and Business Development, Biot Korea Inc., Gwangju 61001, ${ }^{5}$ Department of Otolaryngology, Chonnam Na- \\ tional University Medical School, Gwangju 61469, Korea
}

ARTICLE INFO

Received June 18, 2020

Revised October 12, 2020

Accepted October 12, 2020

*Correspondence

Gwang-Won Cho

E-mail: gwcho@chosun.ac.kr

Key Words

Epigenetics

Histone methyltransferase

Neurodegenerative disease

Oxidative stress

Transcription factors

\#These authors contributed equally to this work.

\begin{abstract}
Oxidative stress-induced neurodegeneration is one of several etiologies underlying neurodegenerative disease. In the present study, we investigated the functional role of histone methyltransferase G9a in oxidative stress-induced degeneration in human SH-SY5Y neuroblastoma cells. Cell viability significantly decreased on $\mathrm{H}_{2} \mathrm{O}_{2}$ treatment; however, treatment with the $\mathrm{G} 9$ a inhibitor $\mathrm{BIX01294}$ partially attenuated this effect. The expression of neuron-specific genes also decreased in $\mathrm{H}_{2} \mathrm{O}_{2}$ treated cells; however, it recovered on G9a inhibition. $\mathrm{H}_{2} \mathrm{O}_{2}$-treated cells showed high levels of $\mathrm{H} 3 \mathrm{~K} 9 \mathrm{me} 2$ (histone $\mathrm{H} 3$ demethylated at the lysine 9 residue), which is produced by G9a activation; BIX01294 treatment reduced aberrant activation of G9a. $\mathrm{H} 3 \mathrm{~K} 9 \mathrm{me} 2$ occupancy of the RE-1 site in neuron-specific genes was significantly increased in $\mathrm{H}_{2} \mathrm{O}_{2}$-treated cells, whereas it was decreased in BIX01294-treated cells. The differentiation of $\mathrm{H}_{2} \mathrm{O}_{2}$-treated cells also recovered on G9a inhibition by BIX01294. Consistent results were observed when used another G9a inhibitor UCN0321. These results demonstrate that oxidative stress induces aberrant activation of G9a, which disturbs the expression of neuron-specific genes and progressively mediates neuronal cell death. Moreover, a G9a inhibitor can lessen aberrant G9a activity and prevent neuronal damage. G9a inhibition may therefore contribute to the prevention of oxidative stress-induced neurodegeneration.
\end{abstract}

\section{INTRODUCTION}

Neurodegenerative diseases are caused by neuronal cell death and rapid neuronal dedifferentiation processes, which result in severe nervous system dysfunction. For several decades, many research groups have investigated methods to prevent these diseases; during these investigations, the researchers found that neuronal cell death in these diseases is associated with diverse factors, including hypoxia, inflammation, protein misfolding, mitochondrial dysfunction, ethanol exposure, amyloid $\beta$, and both autophagy-mediated and proteasome-mediated protein degradation [1-6]. However, a common underlying factor in these diseases is the presence of aberrant levels of endogenous reactive oxygen species (ROS), which indiscriminately attack cellular components, leading to a variety of consequences. Thus, maintaining appropriate endogenous ROS levels is important for prevention of neurodegenerative diseases.

Changes in gene expression patterns due to epigenetic modifications play a crucial role in the progression of cellular differentiation, which may partly explain the differential gene expression

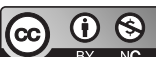

This is an Open Access article distributed under the terms of the Creative Commons Attribution Non-Commercial License, which permits unrestricted non-commercial use, distribution, and reproduction in any medium, provided the original work is properly cited. Copyright @ Korean J Physiol Pharmacol, pISSN 1226-4512, elSSN 2093-3827
Author contributions: H.K. performed the research, and S.J., C.H.J., T.O., and G.C. designed the research. C.H.J., T.O., A.S., and G.C. analyzed the data, and H.K, S.J., C.H.J., T.O., and G.C. wrote the manuscript. T.O. and G.C. supervised the project. 
of various types of cells [7,8]. Epigenetic changes are also associated with many types of diseases, including neurodegenerative diseases $[9,10]$. Recent studies have shown that aberrant repressor element-1 silencing transcription factor (REST)-dependent epigenetic changes are related to ischemia-induced neuronal cell death [11]. During neurodegeneration induced by chronic exposure to hypoxia or ethanol, neurons undergo epigenetic changes and eventually die $[12,13]$. Thus, researchers have focused on elucidating aberrant epigenetic changes that occur in a variety of diseases.

Histone methyltransferase G9a, a component of the REST complex, binds to a repressor element-1 (RE-1) consensus sequence $[14,15]$. This interaction of G9a with the RE-1 region leads to dimethylation of the lysine 9 residue of histone $\mathrm{H} 3$ (H3K9me2), which is associated with repression of RE-1-containing neuronspecific genes $[16,17]$. Aberrant G9a activation due to hypoxia or ethanol exposure increases the risk of neurodegeneration $[18,19]$. Targeted inhibition of G9a by a specific inhibitor [20] (e.g., BIX01294) has beneficial effects on anti-senescence [21] and promotes neuronal differentiation of mesenchymal stem cells [22]; thus, G9a inhibition may positively influence neurodegenerative disorders.

In this study, we examined the functional role of G9a in oxidative stress-induced neurodegeneration. We found that aberrant activation of G9a causes epigenetic disruption of the expression of neuron-specific genes in human neuroblastoma cells exposed to $\mathrm{H}_{2} \mathrm{O}_{2}(12 \mathrm{~h}$ ), thereby leading to neurodegeneration. Furthermore, the G9a inhibitor BIX01294 attenuates this neurodegeneration.

\section{METHODS}

\section{Cell culture}

The SH-SY5Y human neuroblastoma cell line was purchased from KCLB (Korean Cell Line Bank, Seoul, Korea). SH-SY5Y cells were cultured in a 100-mm dish (SPL, Pocheon, Korea) in accordance with the manufacturer's recommendations.

\section{3(4,5-Dimethylthiazol-2-yl)-2,5-diphenyltetrazolium bromide (MTT) assay}

Cell viability of BIX01294-treated cells was evaluated using the MTT assay (Sigma-Aldrich, St. Louis, MO, USA), in accordance with the manufacturer's instructions. Briefly, $2 \times 10^{3}$ SH-SY5Y neuroblastoma cells were seeded onto 96 -well plates. The next day, cells were incubated with $0-2 \mu \mathrm{M}$ of BIX01294 for $12 \mathrm{~h}$ or exposed to $\mathrm{H}_{2} \mathrm{O}_{2}$ and then subjected to the MTT assay.

\section{Quantitative polymerase chain reaction (real-time PCR)}

Total RNA was isolated from SH-SY5Y cells using RNAiso reagent (TAKARA, Shiga, Japan), in accordance with the manufacturer's instructions. Three micrograms of total RNA were used for reverse transcription with the AMPIGENE cDNA Synthesis Kit (Enzo, Farmingdale, NY, USA). cDNA was amplified using the Power SYBR Green PCR Master Mix (Applied Biosystems Inc., Foster City, CA, USA) with gene-specific primers for human MAP-2, NF-M, NEFH, SYN1, SCN3A, SNAP25, CACNA1A, and $\beta$-actin. The real-time PCR cycling parameters were as follows: $95^{\circ} \mathrm{C}$ for $10 \mathrm{~min}$, followed by 40 cycles of $15 \mathrm{sec}$ at $95^{\circ} \mathrm{C}$ and $1 \mathrm{~min}$ at $60^{\circ} \mathrm{C}$. The primers used in this study were synthesized by GenoTech (GenoTech Corp., Daejeon, Korea) and IDT (Integrated DNA Technologies Inc., Coralville, IA, USA). The primers are summarized in Supplementary Table 1.

\section{Chromatin immunoprecipitation}

SH-SY5Y cells were incubated with or without $1 \mu \mathrm{M}$ BIX01294 for $12 \mathrm{~h}$, then treated with $100 \mu \mathrm{M} \mathrm{H}_{2} \mathrm{O}_{2}$ for $12 \mathrm{~h}$. H3K9me2containing chromatin was precipitated by an anti-H3K9me2 antibody (Merck, Darmstadt, Germany) and subjected to chromatin immunoprecipitation using the ChIP Assay Kit (Merck), in accordance with the manufacturer's instructions. The details of this method were described in our previous study [22]. For real-time PCR analysis, $3 \mu \mathrm{DNA}$ was used for each reaction with specific primers for the proximal region of genomic DNA in human NF$M, S Y N 1, S N A P-25$, and MAP-2 genes. The primer sequences are summarized in Supplementary Table 2.

\section{Immunoblotting}

Cells were incubated with $100 \mu$ l of radioimmunoprecipitation assay (RIPA) buffer containing protease and dephosphatase inhibitors (Santa Cruz Biotechnology, Dallas, TX, USA) for 30 $\min$ at $4^{\circ} \mathrm{C}$ and then centrifuged at $16,000 \times g$ for $20 \mathrm{~min}$. Total protein was then subjected to immunoblotting using antibodies against Cleaved caspase 3 (1:500), H3K9me2 (1:200; Merk), Histone 3 (1:1,000; Merk), Nestin (1:500), NF-M (1:500), MAP-2 (1:500), GAPDH (1:1,000; Santa Cruz Biotechnology), or $\beta$-actin (1:5,000; Sigma-Aldrich), followed by the appropriate horseradish peroxidase-conjugated secondary antibodies (1:10,000; Jackson ImmunoResearch Laboratories, West Grove, PA, USA). Details of primary and secondary antibodies are summarized in Supplementary Tables 3 and 4 .

\section{Neuronal differentiation}

SH-SY5Y cells were incubated with or without $1 \mu \mathrm{M}$ BIX01294 for $12 \mathrm{~h}$ (or $7 \mathrm{nM}$ UCN0321 for $12 \mathrm{~h}$ ). Then, cells were washed 
with phosphate-buffered saline (PBS) and treated with $100 \mu \mathrm{M}$ $\mathrm{H}_{2} \mathrm{O}_{2}$ for $12 \mathrm{~h}$. The cells were washed twice with PBS and returned to neuronal induction medium (Dulbecco's Modified Eagle Medium-F12, $0.1 \%$ fetal bovine serum [FBS], and $1 \mu \mathrm{M}$ retinoic acid) for 3-7 days. Control SH-SY5Y cells were incubated in 10\% FBS medium for 3 days. Images were captured with a digital camera (i-Solution IMTcam3; Canon, Tokyo, Japan) under a microscope (Nikon ECLIPSE TS100; Nikon, Tokyo, Japan).

\section{RESULTS}

\section{BIX01294 is protective against oxidative stress- induced apoptosis in neuronal cells}

To examine the toxicity of BIX01294, SH-SY5Y cells were incubated with 0-2 $\mu \mathrm{M}$ of BIX01294 for $12 \mathrm{~h}$. No cytotoxicity was observed with $\leq 1.5 \mu \mathrm{M}$ BIX01294, whereas viability decreased by approximately $10 \%$ on exposure to $2 \mu \mathrm{M}$ BIX01294 (Fig. 1A). To estimate cell viability in $\mathrm{H}_{2} \mathrm{O}_{2}$-treated cells, $\mathrm{SH}-\mathrm{SY} 5 \mathrm{Y}$ cells were treated with 0-100 $\mu \mathrm{M} \mathrm{H}_{2} \mathrm{O}_{2}$ for $12 \mathrm{~h}$. Survival rates decreased in a dose-dependent manner (Fig. 1B) and reached $60 \%$ in $100 \mu \mathrm{M}$ $\mathrm{H}_{2} \mathrm{O}_{2}$-treated cells.

To examine the protective effect of BIX01294 in oxidative stress-induced neuronal cells, SH-SY5Y cells were incubated with $0-1.5 \mu \mathrm{M}$ BIX01294 for $12 \mathrm{~h}$ (Fig. 1C) or $1 \mu \mathrm{M}$ BIX01294 for 0-24 h (Fig. 1D). Cells were then exposed to $100 \mu \mathrm{M} \mathrm{H}_{2} \mathrm{O}_{2}$ for $12 \mathrm{~h}$. Maximal protective effects were observed when cells were incubated with $1 \mu \mathrm{M}$ BIX01294 for $12 \mathrm{~h}$ (Fig. 1C, D). These effects were confirmed by immunoblot analysis with apoptotic marker cleaved caspase-3. Cleaved caspase-3 levels increased when cells were exposed to $\mathrm{H}_{2} \mathrm{O}_{2}$, but not in cells that were pre-incubated with $1 \mu \mathrm{M}$ BIX01294 (Fig. 1E). The protein expression levels were quantified (Fig. 1F). These results suggest that BIX01294 treatment prevents cell damage by oxidative stress.
A

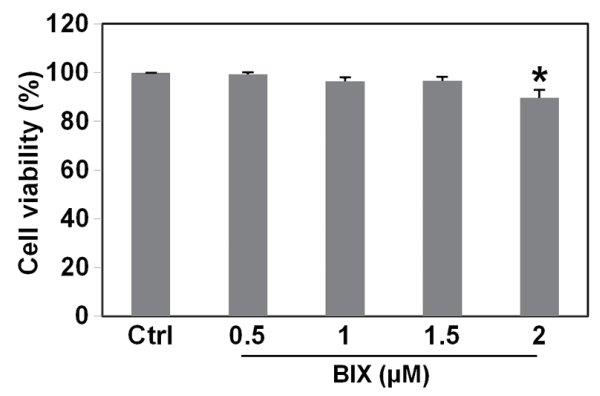

C

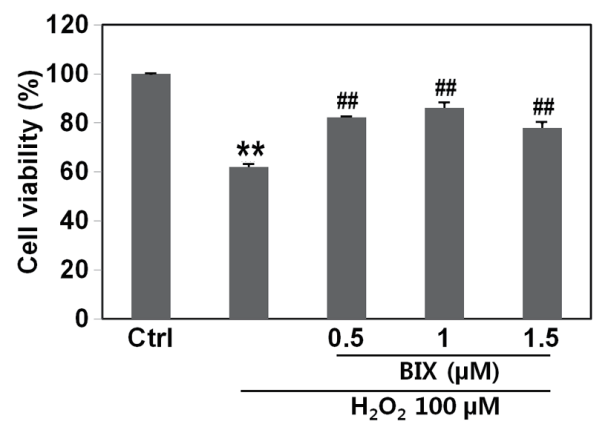

E

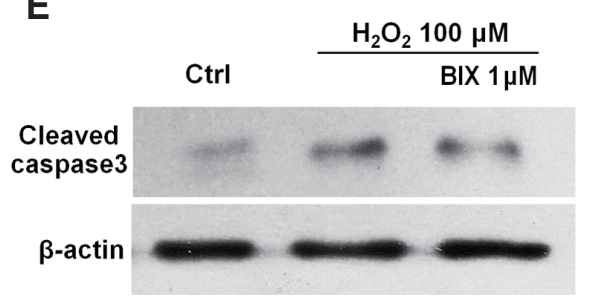

B

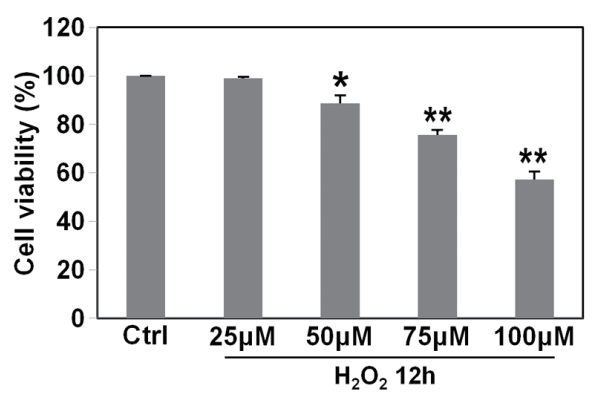

D

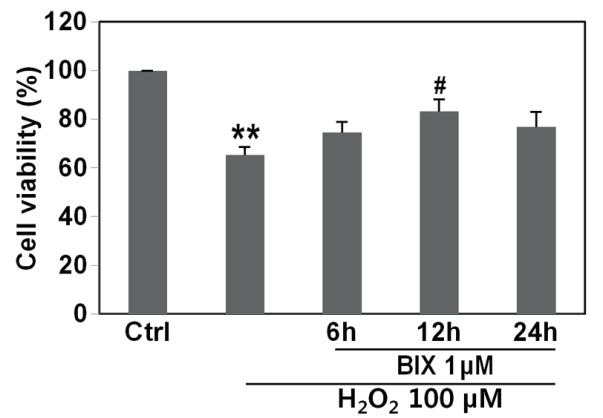

F

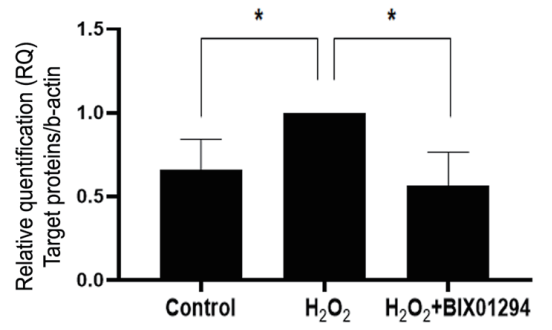

Fig. 1. Protective effects of BIX01294 in oxidative stress-damaged SH-SY5Y cells. (A) Toxicity was measured by the MTT assay in SH-SY5Y cells that were treated with 0-2 $\mu \mathrm{M}$ BIX01294 (t-test, ${ }^{*} \mathrm{p}<0.05$, mean $\pm S D, n=3$ ). (B) SH-SY5Y cells were treated with 0-100 $\mu \mathrm{M} \mathrm{H}_{2} \mathrm{O}_{2}$ for $12 \mathrm{~h}$ (t-test, ${ }^{*} \mathrm{p}<0.05,{ }^{* *} \mathrm{p}<0.005$, mean $\pm S D, n=3$ ). (C) SH-SY5Y cells were

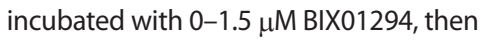
treated with or without $100 \mu \mathrm{M} \mathrm{H}_{2} \mathrm{O}_{2}(\mathrm{t}$ test, ${ }^{\#{ }^{*}} \mathrm{p}^{* * *} \mathrm{p}<0.005$, mean $\pm S D, n=3$ ). (D) SH-SY5Y cells were treated with 1 $\mu \mathrm{M}$ BIX01294 for 0-24 $\mathrm{h}$, then treated with or without $100 \mu \mathrm{M} \mathrm{H}_{2} \mathrm{O}_{2}$ for $12 \mathrm{~h}$ (ttest, ${ }^{*} p<0.05,{ }^{* *} p<0.005$, mean $\pm S D$, $n=3)$. (E, F) Immunoblot analysis was performed with antibodies specific to cleaved caspase-3 in $\mathrm{H}_{2} \mathrm{O}_{2}$-treated $\mathrm{SH}$ SY5Y cells, with or without BIX01294 treatment (t-test, ${ }^{*} p<0.05$, mean $\pm S D$, $\mathrm{n}=3$ ). Ctrl indicates control cells, which

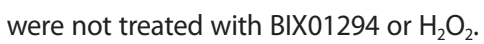
BIX indicates BIX01294. 


\section{Oxidative stress-induced reduction in the expression of neuron-specific genes was attenuated by G9a inhibition}

To further investigate the influence of $\mathrm{H}_{2} \mathrm{O}_{2}$ on neuronal cells, SH-SY5Y cells were treated with or without $1 \mu \mathrm{M}$ BIX01294 for $12 \mathrm{~h}$, then treated with $100 \mu \mathrm{M} \mathrm{H}_{2} \mathrm{O}_{2}$ for $12 \mathrm{~h}$. Gene expression was measured by real-time PCR with primers for neuron-specific genes: NF-M, NEFH, MAP-2, SCN3A, CACNA1A, Syn1, and SNAP25. As shown in Fig. 2A, expression of the tested genes decreased in $\mathrm{H}_{2} \mathrm{O}_{2}$-treated cells; however, expression levels of NF$M, N E F H, M A P-2, C A C N A 1 A$, and SYN1 showed significant recovery on treatment with BIX01294. Immunoblot analysis was performed with antibodies against neuron-specific proteins (Nestin, NF-M, and MAP-2); this analysis showed that protein levels recovered on treatment with BIX01294 (Fig. 2B). These findings indicate that neuron-specific markers decreased upon exposure to $\mathrm{H}_{2} \mathrm{O}_{2}$-induced oxidative stress, and that the expression levels of these markers were restored on treatment with BIX01294.

\section{Oxidative stress-induced downregulation of RE-1- containing neuronal genes was mediated by aberrant activation of G9a}

The G9a inhibitor BIX01294 can partially prevent cell damage induced by oxidative stress; thus, we next examined the relationship between oxidative stress and G9a. Activated G9a dimethylates the lysine 9 residue of histone $\mathrm{H} 3$ (H3K9), thereby producing dimethyl-H3K9 (H3K9me2) [23]. We performed immunoblot analysis using the $\mathrm{H} 3 \mathrm{~K} 9 \mathrm{me} 2$ antibody to assess G9a activity. $\mathrm{H} 3 \mathrm{~K} 9 \mathrm{me} 2$ was increased $55.6 \%$ (1.8-fold) in $\mathrm{H}_{2} \mathrm{O}_{2}$-treated cells (vs. control cells) and decreased by as much as $17.7 \%$ with BIX01294

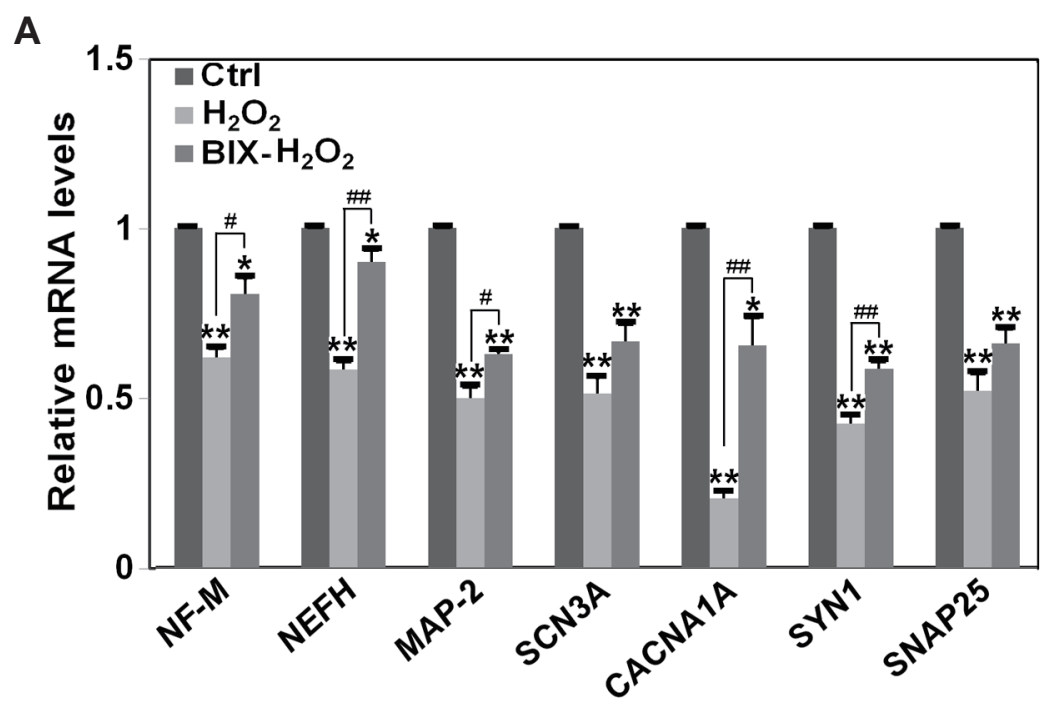

B

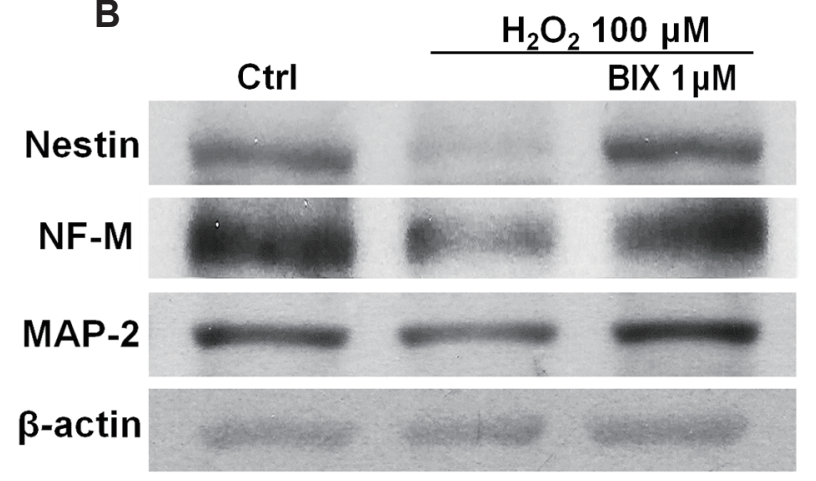

C

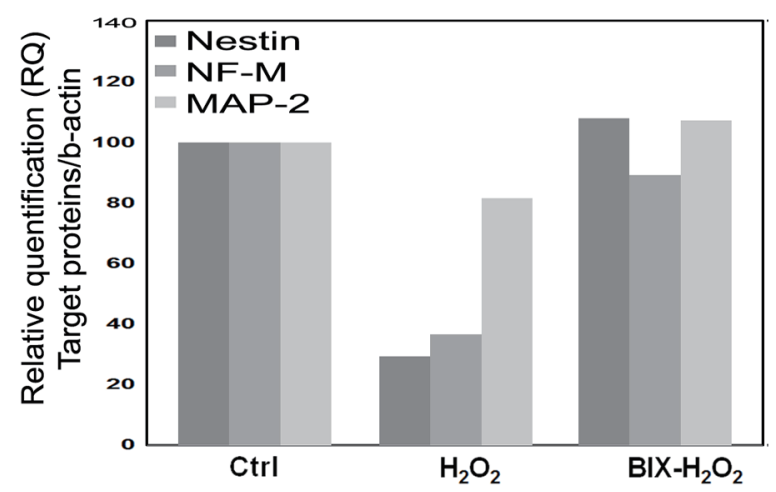

Fig. 2. Oxidative stress-induced reduction in the expression of neuron-specific genes was partially restored by G9a inhibition. (A) The expression levels of neuron-specific genes in $\mathrm{H}_{2} \mathrm{O}_{2}$-treated SH-SY5Y cells $\left(\mathrm{H}_{2} \mathrm{O}_{2}\right)$ and in SH-SY5Y cells treated with both $\mathrm{H}_{2} \mathrm{O}_{2}$ and BIX01294 (BIX- $\left.\mathrm{H}_{2} \mathrm{O}_{2}\right)$ were measured by real-time PCR; these expression levels were compared with those in SH-SY5Y cells in normal conditions (Ctrl; t-test, ${ }^{*} p,{ }^{*} p<0.05$, ${ }^{* \#} p$, ${ }^{* *} p<$ 0.005 , mean $\pm \mathrm{SD}, n=4)$. ${ }^{*} \mathrm{p},{ }^{* *} \mathrm{p}$ (vs. control), ${ }^{*} \mathrm{p},{ }^{*}{ }^{*} \mathrm{p}$ (vs. $100 \mu \mathrm{M} \mathrm{H}_{2} \mathrm{O}_{2}$-treated cells). (B) The neuron-specific proteins Nestin, NF-M, and MAP-2 were examined by immunoblot analysis in $\mathrm{H}_{2} \mathrm{O}_{2}$-treated $\mathrm{SH}-\mathrm{SY} 5 \mathrm{Y}$ cells with or without BIX01294 treatment. (C) Protein expression levels were quantified using ImageJ software. $\beta$-actin was used as the internal standard. 
treatment (vs. $\mathrm{H}_{2} \mathrm{O}_{2}$-treated cells) (Fig. 3A). To further examine these effects in $\mathrm{H}_{2} \mathrm{O}_{2}$ - and BIX01294-treated cells, chromatin immunoprecipitation (ChIP) assays for $\mathrm{H} 3 \mathrm{~K} 9 \mathrm{me} 2$ were performed with RE-1 site-containing neuron-specific genes. H3K9me2 occupancy of the RE-1 site of the neuron-specific genes NF-M, Syn1, SNAP-25, and Map-2 was significantly increased on exposure of cells to $\mathrm{H}_{2} \mathrm{O}_{2}$, whereas it was significantly decreased on treatment with BIX01294 (significant decrease for NF-M, SNAP-25, and Map-2; no significant difference for Syn1; Fig. 3B). These results indicate that oxidative stress induces aberrant activation of G9a, thereby disrupting neuron-specific gene expression.

\section{Inhibition of G9a prevents neuronal cell damage caused by exposure to $\mathrm{H}_{2} \mathrm{O}_{2}$}

To investigate the mechanism by which $\mathrm{H}_{2} \mathrm{O}_{2}$-damaged cells recover on inhibition of G9a, SH-SY5Y cells were incubated with or without BIX01294, prior to exposure to $\mathrm{H}_{2} \mathrm{O}_{2}$. The cells were then differentiated in neuronal induction medium. As shown in Fig. 4A, differentiation (3 days) declined in $\mathrm{H}_{2} \mathrm{O}_{2}$-treated cells and partially recovered on BIX01294 treatment; this was most evident at 7 days after differentiation (Fig. 4A). To confirm these results, immunoblot analyses were performed with neuron-specific antibodies to NF-M and MAP-2, which showed that expression levels of neuronal proteins decreased in $\mathrm{H}_{2} \mathrm{O}_{2}$-treated cells and increased on treatment with BIX01294 (Fig. 4B, C). Consistent results were obtained when used another G9a inhibitor UCN0321 (Fig. 5).

\section{DISCUSSION}

The human body contains a variety of specialized cell types with multiple functional roles. Although all human cells share the same genome, they differ in structure, morphology, function, and gene expression. Such differences are achieved through several means, including epigenetic modifications [7,8]. Epigenetic modifications are associated with both cellular differentiation and degeneration processes [24-26]. Our previous studies have shown that processes involved in the modulation of histone methylation, acetylation, and DNA methylation can promote neuronal differentiation and stimulate the expression of neuron-specific genes [22,27-29].

Histone methyltransferase G9a regulates the expression of RE1-containing neuron-specific genes through binding to the REST complex [30]. Notably, G9a is activated by a variety of stimuli, including ethanol exposure and hypoxia, which can cause neurodegeneration $[18,19,31]$. A previous study showed that inhibition of G9a reverses $\beta$-amyloid-induced deficits in hippocampal neurons [32]. Thus, inhibiting aberrant activation of G9a is important for prevention of neurodegenerative diseases. In the present study, we investigated the relationship between neuronal cell death and aberrant activation of G9a due to oxidative stress exposure in $\mathrm{SH}$ SY5Y neuroblastoma cells. As shown in Fig. 1B, cell viabilities decreased in $\mathrm{H}_{2} \mathrm{O}_{2}$-treated SH-SY5Y cells; such changes were partly accompanied by reduced levels of neuron-specific gene expression (Fig. 2).

Treatment with the G9a inhibitor BIX01294 prevented cell

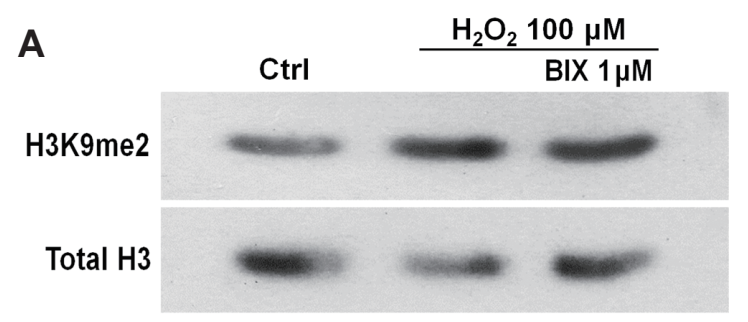

B

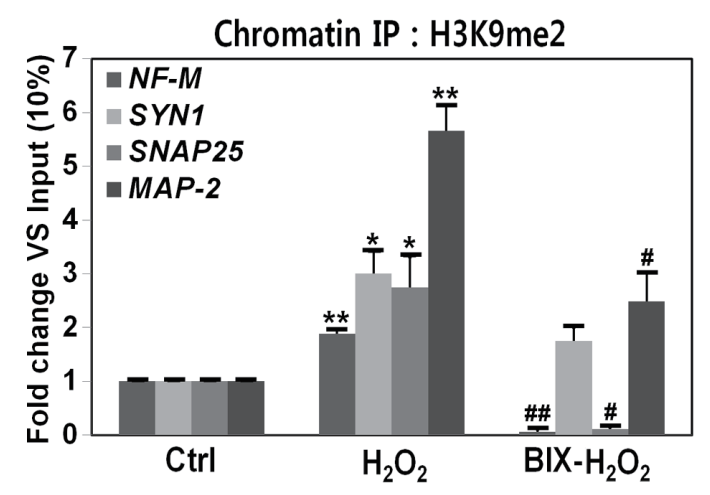

Fig. 3. G9a is aberrantly activated by oxidative stress and disrupts the expression of RE-1-containing neuron-specific genes. (A) G9a activity was measured by immunoblot analysis with an antibody specific for H3K9me2 (top panel). The ratio of H3K9me2:H3 expression was measured using ImageJ software (bottom panel) (t-test, ${ }^{*} \mathrm{p}<0.05$, mean $\pm \mathrm{SD}, \mathrm{n}=4$; vs. control). (B) For the ChIP assay, $\mathrm{SH}-\mathrm{SY} 5 Y$ cells treated with $\mathrm{H}_{2} \mathrm{O}_{2}$, with or without $\mathrm{BIX01294}$ treatment (indicated by $\mathrm{H}_{2} \mathrm{O}_{2}$ or $\mathrm{BIX}-\mathrm{H}_{2} \mathrm{O}_{2}$ ), were immunoprecipitated with $\mathrm{H} 3 \mathrm{~K} 9$ me2 antibody, then analyzed by real-time PCR using primers for the RE-1 sites of NF-M, SYN1, SNAP25, and MAP-2 genes. ${ }^{*} \mathrm{p},{ }^{* *} \mathrm{p}$ (vs. control), ${ }^{*} \mathrm{p},{ }^{\# \#} \mathrm{p}$ (vs. $100 \mu \mathrm{M} \mathrm{H}_{2} \mathrm{O}_{2}$-treated cells) (t-test, ${ }^{*} \mathrm{p}<0.05$, mean $\pm \mathrm{SD}$, $n=3$ ). 


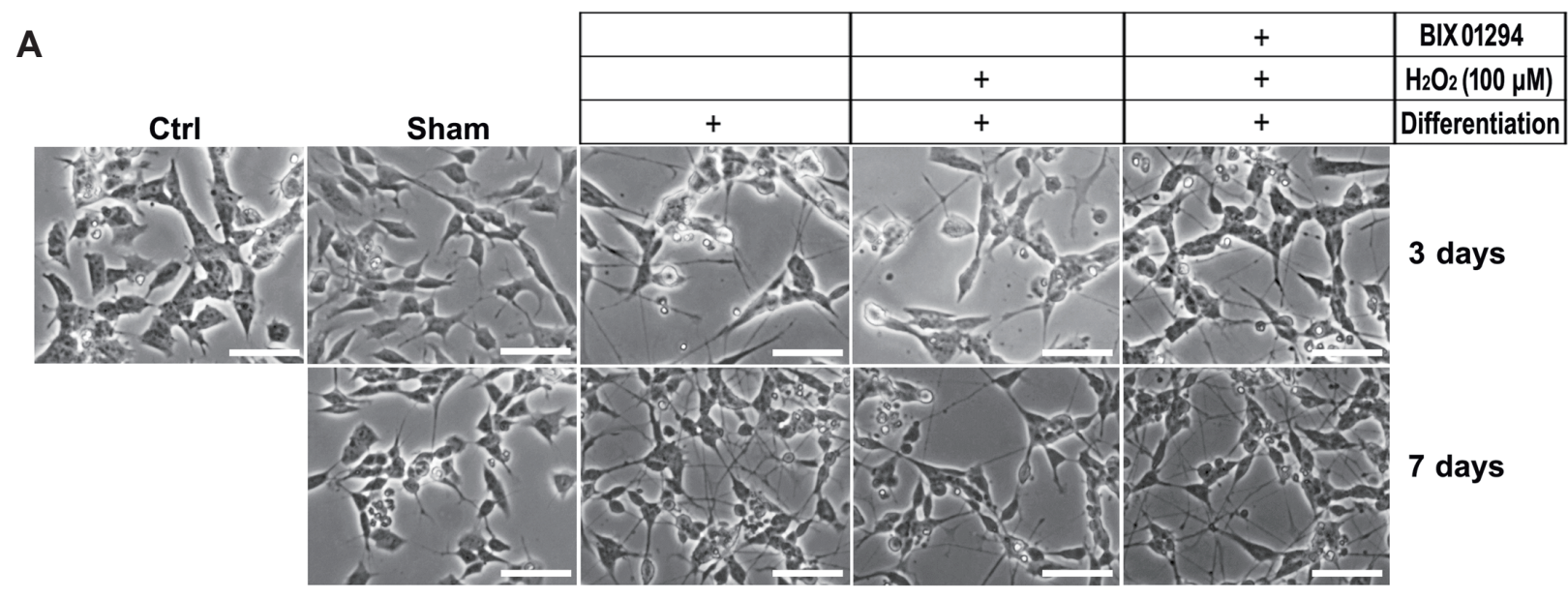

B

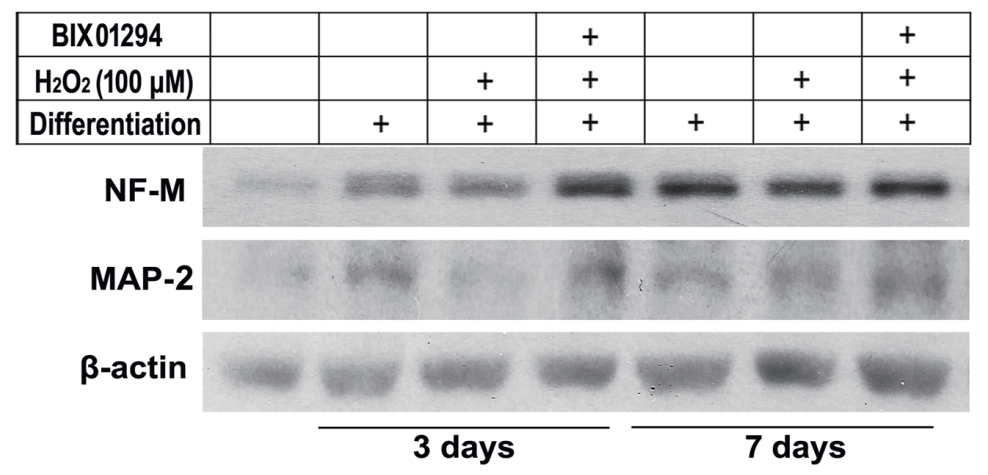

C

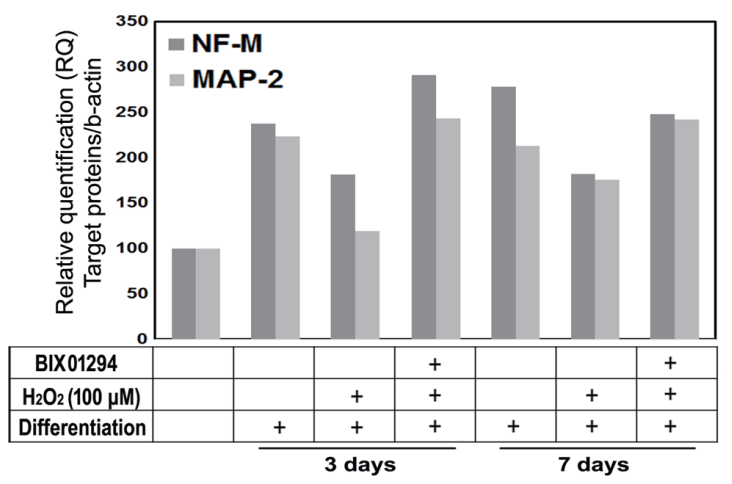

Fig. 4. Neuronal differentiation in $\mathrm{H}_{2} \mathrm{O}_{2}$-treated SH-SY5Y cells recovered on inhibition of G9a. (A) SH-SY5Y cells were differentiated into neuronlike cells for 0-7 days. Each cell was visualized by light microscopy. $(B, C)$ The expression levels of RE-1-containing neuron-specific proteins were examined using antibodies specific to NF-M and MAP-2 in $\mathrm{H}_{2} \mathrm{O}_{2}$-treated differentiated SH-SY5Y cells, with or without BIX01294 treatment. Ctrl indicates controls, which were non-differentiated SH-SY5Y cells. Sham indicates incubation with FBS $0.1 \%$ medium. $\beta$-actin was used as the internal standard.

damage and restored the expression of neuron-specific genes (Fig. 1C-E and Fig. 2A, B). This indicated that the expression of neuronal genes may be disturbed by oxidative stress, thereby leading to neuronal cell death; moreover, G9a inhibition can attenuate these effects. Thus, the effects of oxidative damage are only partially mitigated on treatment with BIX01294; this may be a result of partial recovery of neuron-specific gene expression, and there may be a need for ROS scavenging by antioxidants to facilitate complete recovery.

The reduction of neuron-specific proteins is a critical element in the progression of neurodegeneration [33-35]. Sustained expression of neuron-specific genes may delay degeneration and attenuate neuronal cell death. The expression of neuron-specific marker genes is reduced by exposure to $\mathrm{H}_{2} \mathrm{O}_{2}$ for $12 \mathrm{~h}$ and recovers when treated with the G9a inhibitor BIX01294; notably, G9a activity was elevated in cells exposed to $\mathrm{H}_{2} \mathrm{O}_{2}(12 \mathrm{~h})$. As shown in Fig. 3A, when SH-SY5Y cells were treated with $100 \mu \mathrm{M}$ $\mathrm{H}_{2} \mathrm{O}_{2}$, H3K9me2 levels significantly increased. Furthermore, H3K9me2 levels in SH-SY5Y cells showed a weakly decreasing trend on treatment with BIX01294. This suggests that H3K9me2 may be moderately increased on exposure to oxidative stress, in the absence of G9a. The results of the ChIP assay showed that $\mathrm{H} 3 \mathrm{~K} 9 \mathrm{me} 2$ was significantly increased in the proximal region of RE-1-containing neuron-specific genes in $\mathrm{H}_{2} \mathrm{O}_{2}$-treated cells, compared with that in the same region in control cells (Fig. 3B); however, $\mathrm{H} 3 \mathrm{~K} 9 \mathrm{me} 2$ decreased in cells that were treated with both BIX01294 and $\mathrm{H}_{2} \mathrm{O}_{2}$. This suggests that oxidative stress causes activation of G9a, thereby interrupting the transcription of neuronspecific genes. Thus, aberrant expression of neuronal genes may interfere with the function of neuronal cells, and may lead to transformation and damage, ultimately resulting in cell death of varying severity. Treatment with BIX01294 may restore the expression of neuron-specific genes.

The activation of G9a blocks neuronal differentiation and leads to neurodegeneration; thus, we examined neuronal differentiation potency by using SH-SY5Y cells treated with or without BIX01294, prior to $\mathrm{H}_{2} \mathrm{O}_{2}$ exposure. The neuronal differentiation rate decreased in $\mathrm{H}_{2} \mathrm{O}_{2}$-exposed $\mathrm{SH}-\mathrm{SY} 5 \mathrm{Y}$ cells; this change was attenuated on inhibition of G9a (Fig. 4A, B). These results suggest that BIX01294 can restore the expression levels of neuron-specific proteins that were downregulated on oxidative stress-induced aberrant activation of G9a. 


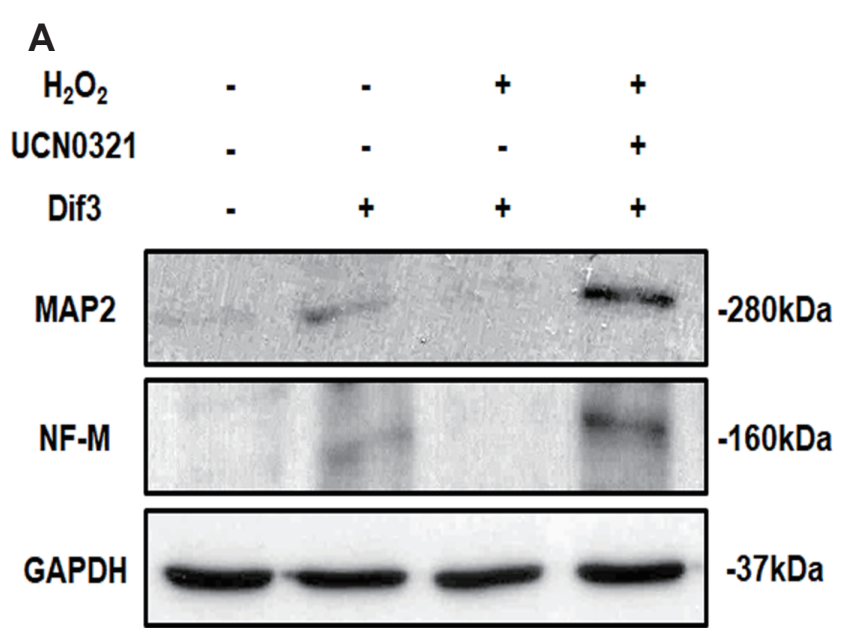

B

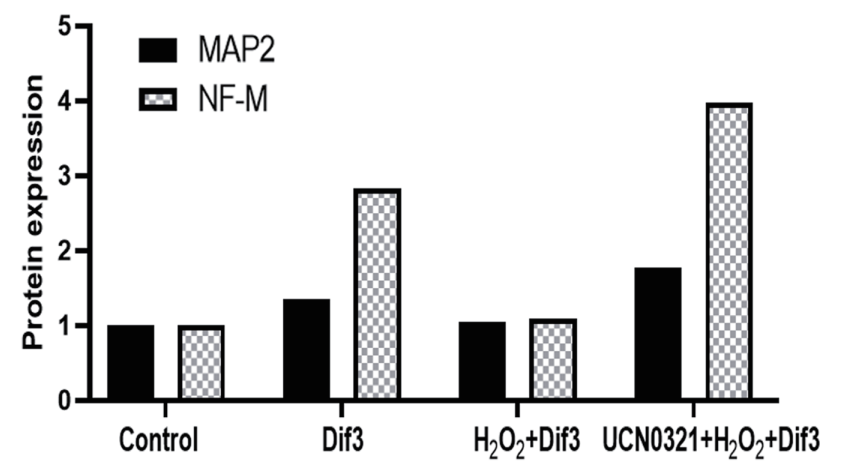

Fig. 5. Recovery by another G9a inhibitor UCNO321 in $\mathrm{H}_{2} \mathrm{O}_{2}$-treated SH-SY5Y cells. (A) SH-SY5Y cells were differentiated into neuronal cells for 3 days. The expression levels of NF-M and MAP-2 were measured in $\mathrm{H}_{2} \mathrm{O}_{2}$-treated cells, with or without UCN0321 treatment. GAPDH was used as the internal standard. (B) The expression levels were quantified using ImageJ software.

In the present study, we aimed to characterize the relationships among oxidative stress, G9a, and neurodegeneration. However, there were some limitations like, this study was limited to in vitro analysis, need to test with inhibition of G9a gene, and thus may not be entirely reproducible in vivo. Therefore, further studies are needed to confirm these findings regarding the relationships among aberrant activation of G9a, oxidative stress, and neurodegenerative diseases.

Oxidative stress induces aberrant activation of G9a, which leads to epigenetic modification of RE-1-containing neuron-specific genes; this disturbs neuronal gene expression and results in neuronal cell death, which is an important etiology of neurodegenerative diseases. Treatment with the G9a inhibitor BIX01294 can attenuate this aberrant G9a activity and protect against neuronal damage. Thus, the results of the present study suggest that G9a inhibition may provide a useful approach for treatment of neurodegenerative diseases caused by chronic exposure to oxidative stress.

\section{ACKNOWLEDGEMENTS}

This work was supported by a grant from Chosun University (2020).

\section{CONFLICTS OF INTEREST}

The authors declare no conflicts of interest.

\section{SUPPLEMENTARY MATERIALS}

Supplementary data including four tables can be found with this article online at https://doi.org/10.4196/kjpp.2021.25.1.51.

\section{REFERENCES}

1. Kauser H, Sahu S, Panjwani U. Guanfacine promotes neuronal survival in medial prefrontal cortex under hypobaric hypoxia. Brain Res. 2016;1636:152-160.

2. Pradhan SS, Salinas K, Garduno AC, Johansson JU, Wang Q, Manning-Bog A, Andreasson KI. Anti-inflammatory and neuroprotective effects of $\mathrm{PGE}_{2}$ EP4 signaling in models of Parkinson's disease. $J$ Neuroimmune Pharmacol. 2017;12:292-304.

3. Neniskyte U, Fricker M, Brown GC. Amyloid $\beta$ induces microglia to phagocytose neurons via activation of protein kinase Cs and NADPH oxidase. Int J Biochem Cell Biol. 2016;81(Pt B):346-355.

4. Olney JW, Tenkova T, Dikranian K, Qin YQ, Labruyere J, Ikonomidou C. Ethanol-induced apoptotic neurodegeneration in the developing C57BL/6 mouse brain. Brain Res Dev Brain Res. 2002;133:115126.

5. Wang X, Hu X, Yang Y, Takata T, Sakurai T. Nicotinamide mononucleotide protects against $\beta$-amyloid oligomer-induced cognitive impairment and neuronal death. Brain Res. 2016;1643:1-9.

6. Ramesh G, Meisner OC, Philipp MT. Anti-inflammatory effects of dexamethasone and meloxicam on Borrelia burgdorferi-induced inflammation in neuronal cultures of dorsal root ganglia and myelinating cells of the peripheral nervous system. J Neuroinflammation. 2015;12:240.

7. Bernstein BE, Stamatoyannopoulos JA, Costello JF, Ren B, Milosavljevic A, Meissner A, Kellis M, Marra MA, Beaudet AL, Ecker JR, Farnham PJ, Hirst M, Lander ES, Mikkelsen TS, Thomson JA. The NIH Roadmap Epigenomics Mapping Consortium. Nat Biotechnol. 2010;28:1045-1048.

8. ENCODE Project Consortium. An integrated encyclopedia of DNA elements in the human genome. Nature. 2012;489:57-74.

9. Sedivy JM, Banumathy G, Adams PD. Aging by epigenetics--a consequence of chromatin damage? Exp Cell Res. 2008;314:1909-1917.

10. Landgrave-Gómez J, Mercado-Gómez O, Guevara-Guzmán R. Epigenetic mechanisms in neurological and neurodegenerative diseases. Front Cell Neurosci. 2015;9:58.

11. Noh KM, Hwang JY, Follenzi A, Athanasiadou R, Miyawaki T, Greally JM, Bennett MV, Zukin RS. Repressor element-1 silencing 
transcription factor (REST)-dependent epigenetic remodeling is critical to ischemia-induced neuronal death. Proc Natl Acad Sci U S A. 2012;109:E962-E971.

12. Liu H, Le W. Epigenetic modifications of chronic hypoxia-mediated neurodegeneration in Alzheimer's disease. Transl Neurodegener. 2014;3:7.

13. Subbanna S, Nagre NN, Shivakumar M, Umapathy NS, Psychoyos D, Basavarajappa BS. Ethanol induced acetylation of histone at G9a exon1 and G9a-mediated histone $\mathrm{H} 3$ dimethylation leads to neurodegeneration in neonatal mice. Neuroscience. 2014;258:422-432.

14. Thiel G, Ekici M, Rössler OG. RE-1 silencing transcription factor (REST): a regulator of neuronal development and neuronal/endocrine function. Cell Tissue Res. 2015;359:99-109.

15. Zheng D, Zhao K, Mehler MF. Profiling RE1/REST-mediated histone modifications in the human genome. Genome Biol. 2009;10:R9.

16. Ding N, Zhou H, Esteve PO, Chin HG, Kim S, Xu X, Joseph SM, Friez MJ, Schwartz CE, Pradhan S, Boyer TG. Mediator links epigenetic silencing of neuronal gene expression with $\mathrm{x}$-linked mental retardation. Mol Cell. 2008;31:347-359.

17. Ding N, Tomomori-Sato C, Sato S, Conaway RC, Conaway JW, Boyer TG. MED19 and MED26 are synergistic functional targets of the RE1 silencing transcription factor in epigenetic silencing of neuronal gene expression. J Biol Chem. 2009;284:2648-2656.

18. Wang Z, Yang D, Zhang X, Li T, Li J, Tang Y, Le W. Hypoxiainduced down-regulation of neprilysin by histone modification in mouse primary cortical and hippocampal neurons. PLoS One. 2011;6:e19229.

19. Subbanna S, Shivakumar M, Umapathy NS, Saito M, Mohan PS, Kumar A, Nixon RA, Verin AD, Psychoyos D, Basavarajappa BS. G9a-mediated histone methylation regulates ethanol-induced neurodegeneration in the neonatal mouse brain. Neurobiol Dis. 2013;54:475-485.

20. Kubicek S, O'Sullivan RJ, August EM, Hickey ER, Zhang Q, Teodoro ML, Rea S, Mechtler K, Kowalski JA, Homon CA, Kelly TA, Jenuwein T. Reversal of H3K9me2 by a small-molecule inhibitor for the G9a histone methyltransferase. Mol Cell. 2007;25:473-481.

21. Ahn MJ, Jeong SG, Cho GW. Antisenescence activity of G9a inhibitor BIX01294 on human bone marrow mesenchymal stromal cells. Turk J Biol. 2016;40:443-451.

22. Kim HT, Jeong SG, Cho GW. G9a inhibition promotes neuronal differentiation of human bone marrow mesenchymal stem cells through the transcriptional induction of RE-1 containing neuronal specific genes. Neurochem Int. 2016;96:77-83.

23. Shankar SR, Bahirvani AG, Rao VK, Bharathy N, Ow JR, Taneja R. G9a, a multipotent regulator of gene expression. Epigenetics. 2013;8:16-22.

24. Schweizer S, Harms C, Lerch H, Flynn J, Hecht J, Yildirim F, Meisel A, Märschenz S. Inhibition of histone methyltransferases SUV39H1 and G9a leads to neuroprotection in an in vitro model of cerebral ischemia. J Cereb Blood Flow Metab. 2015;35:1640-1647.

25. Zhou Q, Obana EA, Radomski KL, Sukumar G, Wynder C, Dalgard $\mathrm{CL}$, Doughty ML. Inhibition of the histone demethylase Kdm5b promotes neurogenesis and derepresses Reln (reelin) in neural stem cells from the adult subventricular zone of mice. Mol Biol Cell. 2016;27:627-639.

26. Chen X, Du Z, Shi W, Wang C, Yang Y, Wang F, Yao Y, He K, Hao A. 2-Bromopalmitate modulates neuronal differentiation through the regulation of histone acetylation. Stem Cell Res. 2014;12:481-491.

27. Jeong SG, Ohn T, Kim SH, Cho GW. Valproic acid promotes neuronal differentiation by induction of neuroprogenitors in human bone-marrow mesenchymal stromal cells. Neurosci Lett. 2013;554:22-27.

28. Joe IS, Jeong SG, Cho GW. Resveratrol-induced SIRT1 activation promotes neuronal differentiation of human bone marrow mesenchymal stem cells. Neurosci Lett. 2015;584:97-102.

29. Oh YS, Kim SH, Cho GW. Functional restoration of amyotrophic lateral sclerosis patient-derived mesenchymal stromal cells through inhibition of DNA methyltransferase. Cell Mol Neurobiol. 2016;36:613-620.

30. Roopra A, Qazi R, Schoenike B, Daley TJ, Morrison JF. Localized domains of G9a-mediated histone methylation are required for silencing of neuronal genes. Mol Cell. 2004;14:727-738.

31. Subbanna S, Basavarajappa BS. Pre-administration of G9a/GLP inhibitor during synaptogenesis prevents postnatal ethanol-induced LTP deficits and neurobehavioral abnormalities in adult mice. Exp Neurol. 2014;261:34-43.

32. Sharma M, Dierkes T, Sajikumar S. Epigenetic regulation by G9a/ GLP complex ameliorates amyloid-beta 1-42 induced deficits in long-term plasticity and synaptic tagging/capture in hippocampal pyramidal neurons. Aging Cell. 2017;16:1062-1072.

33. Fang Q, Strand A, Law W, Faca VM, Fitzgibbon MP, Hamel N, Houle B, Liu X, May DH, Poschmann G, Roy L, Stühler K, Ying W, Zhang J, Zheng Z, Bergeron JJ, Hanash S, He F, Leavitt BR, Meyer HE, et al. Brain-specific proteins decline in the cerebrospinal fluid of humans with Huntington disease. Mol Cell Proteomics. 2009;8:451-466.

34. Merienne N, Meunier C, Schneider A, Seguin J, Nair SS, Rocher AB, Le Gras S, Keime C, Faull R, Pellerin L, Chatton JY, Neri C, Merienne K, Déglon N. Cell-type-specific gene expression profiling in adult mouse brain reveals normal and disease-state signatures. Cell Rep. 2019;26:2477-2493.e9.

35. Pearl JR, Colantuoni C, Bergey DE, Funk CC, Shannon P, Basu B, Casella AM, Oshone RT, Hood L, Price ND, Ament SA. Genomescale transcriptional regulatory network models of psychiatric and neurodegenerative disorders. Cell Syst. 2019;8:122-135.e7. 